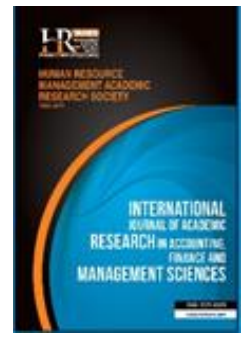

International Journal of Academic Research in Accounting, Finance and Management Sciences

Vol. 8, No.2, April 2018, pp. 208-217

E-ISSN: 2225-8329, P-ISSN: 2308-0337

(C) 2018 HRMARS

www.hrmars.com

To cite this article: Al Shbail, M.O. (2018). The Associations of Internal Audit Quality with Job Burnout and Job Satisfaction Based on Theory of Reasoned Action, International Journal of Academic Research in Accounting Finance and Management Sciences 8 (2): 208-217.

\title{
The Associations of Internal Audit Quality with Job Burnout and Job Satisfaction Based on Theory of Reasoned Action
}

\author{
Mohannad Obeid AL SHBAIL \\ Al-Albayt University, Jordan \\ E-mail: Mohannadobeid87@gmail.com
}

\begin{abstract}
Among the important determinants of long term survival in public shareholding companies, is the quality of internal audit, which is considered among the primary factors affecting the financial information credibility. For this, it is necessary to identify the factors that influence the quality of internal audit, such as internal auditor behavior in the audit process. It is equally important to develop a framework for its determination and to address the factors. Accordingly, this paper developed a theoretical framework to identify individual factors job burnout and job satisfaction - and their influence on dysfunctional audit behavior. The primary aim of this paper is to explain the motivation behind engaging in dysfunctional behaviors in the internal audit environment. Therefore, it provided theoretical evidences about the risk associated with the dysfunctional behaviors that are expected to lead to reduced internal audit quality. In addition, empirical evidence to address the concerns of the Jordanian regulatory authorities of audit quality in the public shareholding companies indicates additional directions for future studies.
\end{abstract}

Key words Dysfunctional audit behavior (DAB), internal audit quality (IAQ), job burnout (JB), job satisfaction (JS)

\author{
Received: 12 Jun $2018 \quad$ (c) The Authors 2018 \\ Revised: $\quad 30$ Jun 2018 Published by Human Resource Management Academic Research Society (www.hrmars.com)
}

Accepted: $\quad 03 \mathrm{Jul} 2018$ This article is published under the Creative Commons Attribution (CC BY 4.0) license. Anyone may reproduce, distribute, translate and create derivative works of this article (for both commercial and noncommercial purposes), subject to full attribution to the original publication and authors. The full terms of this license may be seen at: http://creativecommons.org/licences/by/4.0/legalcode

\section{Introduction}

The global financial crisis, corporate failures and scandals in many countries the raise significant questions about audit quality. On the other hand, The financial crisis were placed audit quality, along with the interconnected issues of the integrity of financial reporting and corporate governance, at the top of the policy agenda once again (e.g. EC 2010). Beside, accounting scandals that were highlighted in major businesses like Enron, Arthur Anderson and World Com have influenced regulators trust on financial statements (Khan et al., 2013). Moreover, with corporate scandals involving auditors regularly appearing in news headlines, there is good reason to believe that auditors have lost sight of their moral compass (Everett and Tremblay, 2014) Of equal concern is that internal auditors failed or Condoned to prevent and apparently failed to detect or report, for instance, the banks' LIBOR scandal in UK, major frauds by bank traders, fixing reported in 2013 (Chambers et al., 2015). On other hand, the financial world has accumulated a large number of cases against auditors, blaming them of negligence in discovering accounting fraud. As a result, many corporations reduced the purchase of audit services (Alshboul and Alrabba, 2014; Thompson et al., 1997).

This in turn led to an increased focus on internal audit which is considered as the backbone of the business accounting. The efficiency of internal audit helps develop the work of the company because the 
financial reports reflect the internal audit quality (Al-Matari et al., 2013). Jordan and other developing countries which have few studies in this field (Abdullah and Al-Araj, 2011; Al Sawalqa and Qtish, 2012; Rahahleh, 2011; Salameh et al., 2011). Yet there is much moral ambiguity in life and managers (and accountants) spend much of their life in moral mazes (Jackall, 1988). Studies to this effect (Ethical behavior) stem from the need to explain audit quality (Zureigat, 2011). Therefore, we need a strategy in order to maintain the high level of internal audit quality that will be further reflected in high quality financial statements. Because the internal audit quality is largely based on the accomplishments of the individual internal auditors associated with the process (Alzeban, 2015). And the knowledge and ability possessed by the auditor (Bonner and Lewis, 1990; Cheng et al., 2009).

To this end, dysfunctional audit behavior (DAB) is associated with decreased audit quality according to AICPA's Public Oversight Board (2000). Where the panel gathered information from peer reviews and surveys of financial executives, internal auditors and external auditing professionals. Their findings indicate that dysfunctional audit behavior (DAB) is a continuing concern for the auditing profession and have influence on audit quality (Paino et al., 2012). Azad (1994) The dysfunctional audit behavior can negatively impact the quality of audit work by internal auditors, which can then impact an entity's external audit. While research on this item has been extensive for external auditors, there has been very little research on (DAB) in the internal auditors field (Ling and Akers, 2010).

Therefore, the internal audit quality has been viewed as a major issue and as such. This is particularly true following the collapse of major companies like Enron, WorldCom, and Parmalat in the early parts of the millennium. Such scandals urged for the need of internal audit quality in terms of irregularities, inconsistencies and auditors behavior. Thus, the present paper provides theoretical, empirical evidence and develops a theoretical framework to identify individual factors of which expected that influence to the quality of internal audit.

\section{Theory of Reasoned Action}

Business ethical behaviour has been examined, documented and researched throughout the past 3 decades, with particular emphasis in the disciplines of management, marketing and accounting. In the context of accounting, the research has sometimes been motivated by congressional investigations like the Dingell Committee, with the urging of external pressure (AICPA Cohen commission and others), entailing the investigation into ethics in the accounting community.

This study continues the line of earlier research in ethics in accounting, which concentrated on documenting the existence of dysfunctional audit behaviors such as premature sign-off. Most of the earlier research, however, has not attempted to use a theoretical base for explaining behavior. When a theory base is lacking, the research is limited in its explanatory power both for the situation examined, and more importantly, for other similar situations. Thus, if an appropriate theory can be found which will explain dysfunctional audit behavior; it is possible to extend the frontiers of understanding to a greater extent.

In social psychology history, the theory of Reasoned Action proposed by Ajzen and Fishbein (1969, 1980 ) is deemed to be one of the top theoretical models used to investigate the individual's decision behavior (Manstead, 2011). Specifically, the information processing method to attitude generation is the theory's core. The theory posits that the prediction of individual's behavior in a certain context can be explained through two self-determining intentions; first, the attitude towards the behavior (positive or negative attitude) and second, the subjective norm, which is the social demand to perform or refrain from performing the examined behavior.

Additionally, Ajzen and Fishbein's (1980) theory of reasoned action was first proposed in 1967 by Fishbein to expound on the attitude-behaviour relationship. It stemmed out from the frustration brought about from the repetitive failure to predict behavior using traditional attitude measures (Terry et al., 1993). Also, the theory of reasoned action (Ajzen and Fishbein, 1980) assumes the rationality of human beings in making systematic utilization of information that is available. Human beings think about the outcomes of their actions prior to their performance of it. The theory also expounds on the connection between beliefs, attitudes, intentions and behaviour, with the top behaviour determinant being behavioural intention, while the direct determinants of behavioral intentions are attitudes towards behavioral performance and 
subjective norm linked to the said behaviour as argued by Ajzen and Fishbein (1980), Fishbein and Middlestadt (1989) and (Montano and Kasprzyk, 2015).

Considering the reasons mentioned above, this study also adopts Ajzen and Fishbein's (1980) theory of reasoned action to interpret intention towards adopting dysfunctional behavior. The theory urges the investigation of cognitive self-regulation, which is deemed to be the top relevant behavioral inclination aspect (Ajzen and Fishbein, 1969). As such, it is suitable to use in studying the intention to adopt dysfunctional behaviors among auditors. Added to this, Ajzen and Fishbein (1980) illustrated that the theory covers the entire behavioral disciplines, being able to explain, clarify and bring about individual behavior in applied contexts. In the field of accounting and auditing studies, especially those that examine factors influencing the behavioral intention among auditors to adopt dysfunctional behaviors, the theory is appropriate to be used as a theoretical framework (Buchan, 2005). Fishbein and Ajzen (1977) explained that the theory is capable of identifying the latent factors influencing the behavioral intention of auditors to involve in a specific behavior and based on it, individual intention is the predictor of behavior.

In the same study caliber, Law (2010) revealed the applicability of the theory in other accounting fields. For the deeper understanding of intention towards accepting dysfunctional audit behaviors among auditors, current authors evidence and recommend the theory's application in the auditing profession. For instance, behavioral dedicated studies like cyber production deviant behavior by Mahatanankoon (2006) and counterproductive behaviour by Vardi and Weitz (2002) are comparable to the examination of behaviors and intentions of auditors. Thus, ample evidence exists on validating the theory's strength and applicability in shedding light on the engagement of internal auditors in dysfunctional audit behaviors such behaviors threaten audit quality (Ling and Akers, 2010; Obeid et al., 2017; Obied et al., 2018; Paino et al., 2010).

Furthermore, Fishbein and Ajzen (1977) explained that behavioral intention determines behavior and assists in explaining the behavior performance or lack of, with given behaviour being influenced by behavioral intention (Beck and Ajzen, 1991). The theory posits that the motive of individuals is independent from the behavioral performance (Beck and Ajzen, 1991) and this intention aspect has top relevance to the intention among auditors to adopt dysfunctional audit behavior. This can be exemplified in a case where an internal auditor is inclined towards performing the behavior at a certain time given the opportunity, he will be likely to engage in dysfunctional behavior despite the negative outcomes (Ajzen, 2005). This can be stressed by stating that theory of reasoned action is applicable in intentional behavior (Ajzen and Fishbein, 1980; Ajzen and Madden, 1986).

\section{Internal audit quality (IAQ)}

Within the professional and regulatory literature, the issue of audit quality has consistently attracted a high level of attention (Beattie et al., 2013). In general, although the audit quality concept is important, it has not been defined by technical standards and up until to date; researchers have failed to arrive at a consensus as to the understanding of its meaning. This is because audit quality is a complex concept and should not be confined to a single general definition (Francis, 2011; Kilgore, 2014). According to Üç and Haxhiraj (2015) There is not a common definition for audit quality term in internal or external (independent) auditing literature. Audit quality is the primary aim behind the process of auditing and it can be reflected by the compliance level of auditors in conducting different phases in the auditing process (DeAngelo, 1981). Added to this, audit quality can also be reflected by the compliance level of auditors in their application of the standards of auditing during the audit process (Anugerah et al., 2014).

On other hand, the internal audit services have a crucial role in decreasing asymmetry in information (Beatty, 1989; Willenborg, 1999), and in minimizing agency problems that exist between managers and shareholders, and between shareholders and creditors (Jensen and Meckling, 1976). This is the reason why owners employ auditors to generate information to be used in management contracting (Antle, 1982; Watts and Zimmerman, 1986). Satisfying the above two roles largely hinges on the quality of internal audit. In addition it leads to the production high quality of Information about the financial statements (Yuniarti, 2011).

\section{Internal Audit Quality (IAQ) and Dysfunctional Audit Behavior (DAB)}


In the audit environment, users of financial statements cannot assess the quality of work during the process of auditing and for this reason, research identifying the drivers of auditors involvement in DAB while auditing is required (Gundry, 2006). In academic literature, such auditor's behavior is evidenced to lead to reduced audit quality (e.g. Watkins et al., 2004; Gundry, 2006; Public Oversight Board, 2000). Regardless of this fact, there is still need for research to determine the causes and determinants of DAB as stressed by Donnelly et al. (2011)

According to Alzeban (2015), internal audit largely hinges on the achievements of internal auditors; in other words, its occurrence negatively and significantly influences audit quality (Khan et al., 2013; Azad, 1994; Ling and Akers, 2010). There is alarming concern in literature as to the widespread practice of DAB among auditors (e.g. Brown-Liburd and Wright, 2011; Kingori, 2003; Ling and Akers, 2010; Paino et al., 2010; Paino et al., 2012; Soobaroyen and Chengabroyan, 2006; Yuen et al., 2011; Yuniarti, 2012). Such behaviors add to pressure in the context of the auditor's workplace environment and it could lead to the auditor's lack of control over such environment (Pierce and Sweeney, 2006).

In this context, dysfunctional behavior is unsuitable behavior that contradicts the audit standards and is an activity that involves the direct or indirect behavior of auditor while auditing that can lessen the quality of audit (Kelley and Margheim, 1990; Otley and Pierce, 1996). Such behavior includes premature sign-off in auditing, time under-reporting, behavioral change, or modifying procedures of auditing (Otley and Pierce, 1996). In case of premature sign-off, the auditor skips steps and does not go through the audit program stages (Alderman and Deitrick, 1982). The above mentioned behaviors could result in negative outcomes and influence the quality of audit (Mindarti and Puspitasari, 2014). With regards to its direct and indirect effects claimed by Donnelly et al. (2003), the former effects include early and incomplete auditing, and modifying the audit procedures (Alderman and Deitrick, 1982; Otley and Pierce, 1995; Rhode, 1978), erroneous auditing process (McDaniel, 1990), and audit phase errors (Kelley and Margheim, 1990).

Studies in literature also shows that most auditors employ divergent practices that goes against the code of ethics and auditing standards (Irawati and Mukhlasin, 2005) and these are covered under DAB and in effect, this leading to audit failure (Donnelly et al., 2003). Such failure can be traced to the extent of the individual's acceptance or exposure towards a negative behavior. The higher the acceptance level, the greater will be the tolerance of the individual to such behavior, after which the acceptance encourages the DAB acceptance when auditors find it difficult to adhere to the standards at work (Donnelly et al., 2003). Other studies Chadegani et al., (2015), reported that according to the National Business Ethics Survey of 2007, in Malaysia, the auditor's unethical behaviors are rampant in the profession and is a crucial issue that influences the work of the auditor. Therefore, it can be assumed that audit's acceptance of DAB influences the quality of internal audit in Jordanian firms and based on this the researcher proposes that;

\section{H1: High levels of dysfunctional behavior relate to decreased internal audit quality.}

\section{Dysfunctional Audit Behavior (DAB) and Job Burnout (JB)}

In theory, literature describes dysfunctional audit behavior (DAB) as behavior that lessens the quality of audit and lead to audit failure (Bryan et al., 2011). The work environment's impact on the employees' behavior and attitudes has long been focused on by behavioral scientists (Aranya and Ferris, 1984) in different professions. For instance, Arches (1991) focused on engineers, Butcher and Engel (1969) focused on medicine, Gaertner (1984) focused on nursing, Meiksins and Watson (1989) focused on social workers and Rosenblatt and Ruvio (1996) focused on education.

Among the professions, it can be stated that auditors face job pressures that stem from the job demands involving precision and professional skepticism in light of the production of high quality audit. Literature addresses this issue through Jones et al. (2010) who revealed attributes of the auditor's career that could lead to challenging situations where a stressful working environment appears. Majority of studies focused on burnout among accountants addressed burnout systems in auditing (e.g. Rose, 1983; Sanders, 1998) in internal audit (Kusel and Deyoub, 1983), and in management accounting (Figler, 1980).

Revealed burnout's influence on dysfunctional behaviors among auditors, which culminates in organizational inefficiency and individual turnover intention, absenteeism, and lowered productivity. In this context, burnout entails feeling emotionally exhausted, perceiving lower personal achievement and depersonalization all these adversely affect the auditor's job outcomes (Utami and Supriyadi, 2013; Jones 
et al., 2010). On other hand, according to Near and Miceli (1989) suggest a possible ethical tension in internal audit environment when to report wrongdoing, but the disclosure of wrongdoing can be detrimental to the organization's profits and reputation. that organizational position can influence auditors behavior As noted by Hooks et al. (1994). Similarly, increased job pressure from stressors leads to increased level of burnout that eventually leads to low auditor's job outcome (Fogarty, 2000; Fogarty and Kalbers, 2006; Fogarty et al., 2000). On the basis of the above discussion, high burnout level in the work environment is expected to result in DAB in Jordanian auditors working in public shareholding firms in Jordan. Therefore, the following hypothesis is proposed;

H2: High level job burnout relates with increased dysfunctional audit behavior (DAB).

\section{Dysfunctional Audit Behavior (DAB) and Job Satisfaction (JS)}

Homans (1961) explained the relationship in light of the Social Exchange theory saying that employees that perceive job dissatisfaction may have a tendency to get involved in deviant behavior in order to get back against the employers for not facilitating a suitable work environment. Such deviant behavior can also be explained by dissatisfied employees who are not concerned of losing their jobs. In contrast, satisfied employees stay away from deviant behavior that could cost them their jobs.

The internal auditing is a profession that is rife with intense stress due to the entailed heavy workloads, deadlines and time and resource limitations. At the same time, internal auditors are almost always exposed to pressure to produce quality work within a limited budget (time and resources) (Brown \& Mendenhall, 1995). Martin and Miller (1986) Finding that job satisfaction partially mediates psychosocial work factors-deviant work behaviors relationship. It is thus crucial to maintain and enhance job satisfaction for quality work (Salehi and Ghaderi, 2012). According to Otley and Pierce (1996) dysfunctional behavior is reaction to the work environment. Such behavior was related by Harini et al. (2010), Paino et al. (2010; 2012) to low audit quality and to this end, the DAB determining factors could explain the why, when and how of the phenomenon.

The relationship between (DAB) and job satisfaction has been investigated by many studies and among them, Bennett and Robinson (2003) and Bowling (2010) revealed that job dissatisfaction related to deviant behavior, with the latter expounding that dissatisfied employees have a greater tendency to involve themselves in (DAB) to release stress. Such a negative correlation between the two variables was also supported by Srivastava (2012) and Dalal's (2005) in meta-analysis. Based on the findings reported by prior studies, dissatisfied auditors are proposed to have a tendency to involve themselves in (DAB) in the context of Jordanian public shareholding firms. The following hypothesis is thus proposed;

H3: Low level of job satisfaction is related with increased dysfunctional audit behavior (DAB).

\section{Theoretical framework}

Based on the limited literature regarding the effect of the DAB on the internal audit quality, this study proposed the following framework that is expected to explain a determinant that influence on internal audit quality, using individual factors (figure 1 ). 


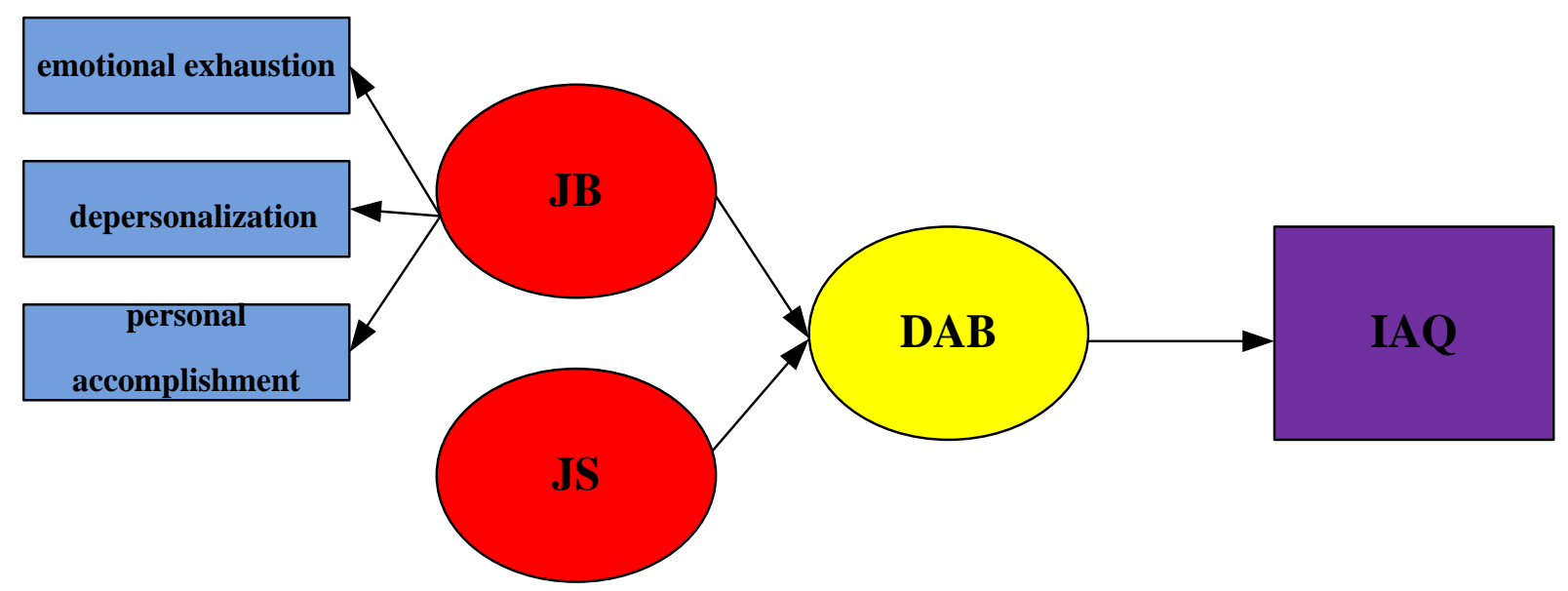

\section{Conclusions and Recommendations}

Figure 1. Theoretical framework

The internal audit is very important inside a firm where the internal audit is regarded as the key element in the application of accounting systems, internal audit standards and this in turn, helps shareholding companies to prosperity and develops. The internal audit is considered as the backbone of the business accounting as it is the section that records all businesses related to the sector. Quality of internal audit will reflect high quality of financial reports. The present study examination of the relationship between dysfunctional behavior and the internal audit quality via individual auditors factors - job burnout and job satisfaction -. There is a notable lack of research in developed as well developing nations regarding the direct association of internal audits quality and DAB.

This study has many recommendations. First, the future researchers to empirically examine using another individual factors affecting on internal audit quality (like turnover intention and organizational commitment) second, the future authors should employ this study in the developing countries considering the necessity of this type of research in this environment. More importantly, future studies could focusing on the auditors' personality and examine the factors that lead to unethical behavior in internal audit environment.

\section{References}

1. Abdullah, \& Al-Araj. (2011). Traditional Audit versus Business Risk Audit: A Comparative StudyCase of Jordan. European Journal of Economics, Finance and Administrative Sciences, 40, 74-91 .

2. Ajzen, I. (2005). Attitudes, personality, and behavior: McGraw-Hill Education (UK.(

3. Ajzen, I., \& Fishbein, M. (1969). The prediction of behavioral intentions in a choice situation. Journal of Experimental Social Psychology, 5(4), 400-416.

4. Ajzen, I., \& Fishbein, M. (1980). Understanding attitudes and predicting social behaviour. Prentice-Hall: Englewood Cliffs, NJ .

5. Ajzen, I., \& Madden, T. J. (1986). Prediction of Goal-Directed Behavior: Attitudes, Intentions, and Perceived Behavioral Control. Journal of Experimental Social Psychology, 22(5), 453-474 .

6. Al-Matari, E. M ,.Al-Swidi, A., \& Fadzil, F. H. B. (2013). The Effect of the Internal Audit and Firm Performance: A Proposed Research Framework. International Review of Management and Marketing, 4(1), 34-41.

7. Al Sawalqa, F., \& Qtish, A. (2012). Internal control and audit program effectiveness: Empirical evidence from Jordan. International Business Research, 5(9), p128.

8. Alderman, C. W., \& Deitrick, J. W. (1982). Auditors' perceptions of time budget pressures and premature sign-offs: A replication and extension. Auditing :A Journal of Practice \& Theory, 1(2), 54-68 .

9. Alshboul, A., \& Alrabba, H. (2014). Evaluating the Effectiveness of Analytical Tools of the Jordanian Audit Bureau in Detecting Accounting Fraud. International Journal of Business and Social Science, $5(11 .($ 
10. Alzeban, A. (2015). The Impact of Culture on the Quality of Internal Audit An Empirical Study. Journal of Accounting, Auditing \& Finance, 30(1), 57-77.

11. Antle, R. (1982). The auditor as an economic agent. Journal of Accounting Research, 503-527.

12. Anugerah, R., Sari, R. N., \& Primadona, E. (2014). Personal characteristics and quality of audit work: study on regional internal audit bodies in Indonesia .

13. Aranya, N., \& Ferris, K. R. (1984). A reexamination of accountants' organizational-professional conflict .Accounting Review, 1-15.

14. Arches, J. (1991). Social structure, burnout, and job satisfaction. Social work, 36(3), 202-206.

15. Azad, A. N. (1994). Time budget pressure and filtering of time practices in internal auditing: a survey. Managerial Auditing Journal, 9(6), 17-25.

16. Beattie, V., Fearnley, S., \& Hines, T. (2013). Perceptions of factors affecting audit quality in the post-SOX UK regulatory environment. Accounting and Business Research, 43(1), 56-81 .

17. Beatty, R. P. (1989). Auditor reputation and the pricing of initial public offerings. Accounting Review, 693-709.

18. Beck, L., \& Ajzen, I. (1991). Predicting dishonest actions using the theory of planned behavior. Journal of Research in Personality, 25(3), 285-301.

19. Bennett, R. J., \& Robinson, S. L. (2003 .(The past, present, and future of workplace deviance research .

20. Board, P. O. (2000). AICPA's public oversight board: Panel of audit effectiveness. American Institute of Certified Public Accountants (AICPA .)

21. Bonner, S. E., \& Lewis, B. L. (1990). Determinants of auditor expertise. Journal of Accounting Research, 1-20.

22. Bowling, N. A. (2010). Effects of job satisfaction and conscientiousness on extra-role behaviors. Journal of Business and Psychology, 25(1), 119-130.

23. Brown-Liburd, H. L., \& Wright, A. M .(2011) .The effect of past client relationship and strength of the audit committee on auditor negotiations. Auditing: A Journal of Practice \& Theory, 30(4), 51-69 .

24. Brown, D., \& Mendenhall, S. (1995). Stress and components of the internal auditor's job. Internal Audit, 10, 31-31.

25. Buchan, H. F. (2005). Ethical decision making in the public accounting profession: An extension of Ajzen's theory of planned behavior. Journal of Business Ethics, 61(2), 165-181 .

26. Butcher, L. L., \& Engel, J. (1969). Behavioral and biochemical effects ofl-DOPA after peripheral decarboxylase inhibition. Brain Research, 15(1), 233-242 .

27. Chadegani, A. A., Mohamed, Z. M., \& Iskandar, T. M. (2015). The Influence of Individual Characteristics on Auditors' Intention to Report Errors .

28. Chambers, A. D., Odar, M., \& Martinov-Bennie, N. (2015). A new vision for internal audit. Managerial Auditing Journal, 30(1 .)

29. Cheng, Y.-S., Liu, Y.-P., \& Chien, C.-Y. (2009). The association between auditor quality and human capital. Managerial Auditing Journal, 24(6), 523-541.

30. Dalal, R. S. (2005). A meta-analysis of the relationship between organizational citizenship behavior and counterproductive work behavior. Journal of applied psychology, 90(6), 1241-1255 .

31. DeAngelo, L. E. (1981). Auditor size and audit quality. Journal of Accounting and Economics, 3(3), 183-199.

32. Donnelly, D. P., Quirin, J. J., \& O'Bryan, D. (2003). Auditor acceptance of dysfunctional audit behavior: An explanatory model using auditors' personal characteristics. Behavioral Research in Accounting, 15(1), 87-110.

33. Donnelly, D. P., Quirin, J. J., \& O'Bryan, D. (2011). Attitudes toward dysfunctional audit behavior: the effects of locus of control, organizational commitment, and position. Journal of Applied Business Research (JABR), 19 (1.)

34. EC. (2010). Audit policy: lessons from the crisis [online]. Brussels: European Commission. Available from :http://ec.europa.eu/internal_market/consultations/docs/2010/audit/green_paper_ audit_en.pdf [Accessed 28 September 2011 
35. Everett, J., \& Tremblay, M.-S. (2014). Ethics and internal audit: Moral will and moral skill in a heteronomous field. Critical Perspectives on Accounting, 25(3), 181-196.

36. Figler, H. R. (1980). Managing stress. Management Accounting, 62(2), 22-28 .

37. Fishbein, M., \& Ajzen, I. (1 .977Belief, attitude, intention, and behavior: An introduction to theory and research .

38. Fishbein, M., \& Middlestadt, S. E. (1989). Using the theory of reasoned action as a framework for understanding and changing AIDS-related behaviors .

39. Fogarty, T. J . (2000) .of Burnout in Accounting: Beyond the Role Stress Model. Behavioral Research. in Accounting, 12 .

40. Fogarty, T. J., \& Kalbers, L. P. (2006). Internal auditor burnout: An examination of behavioral consequences. Advances in Accounting Behavioral Research, 9, 51-86.

41. Fogarty, T. J., Singh, J., Rhoads, G. K., \& Moore, R. K. (2000). Antecedents and consequences of burnout in accounting: Beyond the role stress model. Behavioral Research in Accounting, 12, 31-67 .

42. Francis, J. R. (2011). A framework for understanding and researching audit quality. Auditing: $A$ Journal of Practice \& Theory, 30(2), 125-152 .

43. Gaertner, K. N. (1984). Work satisfaction and family responsibility correlates of employment among nurses. Work and Occupations, 11(4), 439-460 .

44. Gundry, L .C. (2006). Dysfunctional behaviour in the modern audit environment: the effect of time budget pressure and auditors' personality type on reduced audit quality practices .

45. Harini, D., Wahyudin, A., \& Anisykurlillah, I. (2010). Analisis Penerimaan Auditor Atas Dysfunctional Audit Behavior: Sebuah Pendekatan Karakteristik Personal Auditor. Jurnal Akuntansi dalam SNA XIII Purwokerto .

46. Homans, G. C. (1961). Social behavior: Its elementary forms .

47. Hooks, K. L., Kaplan, S. E., Schultz Jr, J. J., \& Ponemon, L .A. (1994). Enhancing communication to assist in fraud prevention and detection; Comment: Whistle-blowing as an internal control mechanism: Individual and organizational considerations. Auditing, 13(2), 86 .

48. Irawati, Y., \& Mukhlasin, T. (2005). Hubungan Karakteristik Personal Auditor Terhadap Tingkat Penerimaan Penyimpangan Perilaku Dalam Audit. Prosiding Simposium Nasional Akuntansi, 929-940 .

49. Jackall, R. (1988). Moral mazes: The world of corporate managers. International Journal of Politics, Culture, and Society, 1(4), 598-614 .

50. Jensen, M. C., \& Meckling, W. H. (1976). Theory of the firm: managerial behavior, agency costs, and ownership structure. Journal of Financial Economics, 3(4), 305-360 .

51. Jones, A., Norman, C. S., \& Wier, B. (2010). Healthy lifestyle as a coping mechanism for role stress in public accounting. Behavioral Research in Accounting, 22(1), 21-41 .

52. Kelley, T., \& Margheim, L. (1990). The impact of time budget pressure, personality, and leadership variables on dysfunctional auditor behavior .Auditing-A Journal Of Practice \& Theory, 9(2), 21-42 .

53. Khan, S., Panatik, S. A., Saat, M. M., \& Perveeen, H. (2013). Auditors' Behavioral Intention Towards Dysfunctional Audit Behavior Applying Theory of Reasoned Action. Sains Humanika, 64(3.)

54. Kilgore, A. (2014). Audit quality. Managerial Auditing Journal, 29(9 .)

55. Kingori, J. L. (2003). The Reduction of Dysfunctional Audit Practices Through the Amplification of Ethical Obligation. Southern Illinois University .

56. Kusel, J., \& Deyoub, N. (1983). Internal auditor burnout. Internal Auditor, 40(5), 22-25 .

57. Law, P. K. (2010). A theory of reasoned action model of accounting students' career choice in public accounting practices in the post-Enron. Journal of Applied Accounting Research, 11(1), 58-73 .

58. Lightner, S. M., Adams, S. J., \& Lightner, K. M. (1982). The influence of situational, ethical, and expectancy theory variables on accountants' underreporting behavior. Auditing: A Journal of Practice \& Theory, 2(1), 1-12.

59. Ling, Q., \& Akers, M. (2010). An Examination Of Underreporting Of Time And Premature Signoffs By Internal Auditors. Review of Business Information Systems .

60. Ling, Q., \& Akers, M. (2010). An Examination Of Underreporting Of Time And Premature Signoffs By Internal Auditors Review of Business Information Systems, 14(4), 37-48 . 
61. Mahatanankoon, P. (2006). Predicting cyber-production deviance in the workplace. International Journal of Internet and Enterprise Management, 4(4), 314-330 .

62. Manstead, A. S. (2011). The benefits of a critical stance: A reflection on past papers on the theories of reasoned action and planned behaviour. British Journal of Social Psychology, 50(3), 366-373 .

63. Martin, J. K., \& Miller, G. A. (1986). Job Satisfaction and Absenteeism Organizational, Individual, and Job-Related Correlates. Work and Occupations, 13(1), 33-46 .

64. McDaniel, L. S. (1990). The effects of time pressure and audit program structure on audit performance. Journal of Accounting Research, 267-285.

65. Meiksins, P. F., \& Watson, J. M. (1989). Professional autonomy and organizational constraint. The Sociological Quarterly, 30(4), 561-585.

66. Mindarti, C. S., \& Puspitasari, E. (2014). The role of organizational commitment on individual characteristics that influence of auditor acceptance of dysfunctional audit behavior .

67. Montano, D. E., \& Kasprzyk, D. (2015). Theory of reasoned action, theory of planned behavior, and the integrated behavioral model. Health behavior: Theory, research and practice, 95-124 .

68. Near, J. P., \& Miceli, M. P. (1989). The internal auditor's ultimate responsibility: The reporting of sensitive issues: Institute of Internal Auditors Research Foundation.

69. Obeid, M., Salleh, Z., \& Mohd Nor, M. (2017). The Mediating Effect of Job Satisfaction on The Relationship Between Personality Traits and Premature Sign-off. Academy of Accounting and Financial Studies Journal, 21(2), 1-17.

70. Obied, M., Salleh, Z., \& Mohd Nor, M. (2018). The effect of ethical tension and time pressure on job burnout and premature sign-off. Journal of Business and Retail Management Research, In press .

71. Otley, D. T., \& Pierce, B. J. (1995). The control problem in public accounting firms: An empirical study of the impact of leadership style. Accounting, Organizations and Society, 20(5), 405-420 .

72. Otley, D. T., \& Pierce, B. J. (1996). Auditor time budget pressure: consequences and antecedents. Accounting, Auditing \& Accountability Journal, 9(1), 31-58 .

73. Paino, H., Ismail, Z., \& Smith, M. (2010). Dysfunctional audit behaviour: an exploratory study in Malaysia. Asian Review of Accounting .173-162, (2)18,

74. Paino, H., Smith, M., \& Ismail, Z. (2012). Auditor acceptance of dysfunctional behaviour: An explanatory model using individual factors. Journal of Applied Accounting Research, 13(1), 37-55 .

75. Pierce, B., \& Sweeney, B. (2006). Perceived adverse consequences of quality threatening behaviour in audit firms. International Journal of Auditing, 10(1), 19-39 .

76. Rahahleh, M. (2011). The impact of multiple authorities that conduct internal control on public fund in the control process in Jordan. European Journal of Economics, Finance and Administrative Sciences, $28,44-60$.

77. Rhode, J. G. (1978). Survey on the influence of selected aspects of the auditor's work environment on professional performance of certified public accountants. Issued as the Independent Auditor's Work Environment: A Survey. New York, NY: AICPA .

78. Rose, R. (1983). Burnout. Journal of Accountancy, 156(4), 22-25.

79. Rosenblatt, Z., \& Ruvio, A. (1996). A test of a multidimensional model of job insecurity: The case of Israeli teachers .Journal of Organizational Behavior, 17(s 1), 587-605.

80. Salameh, R., Al-Weshah, G., Al-Nsour, M., \& Al-Hiyari, A. (2011). Alternative Internal Audit Structures and Perceived Effectiveness of Internal Audit in Fraud Prevention: Evidence from Jordanian Banking Industry. Canadian Social Science, 7(3), 40-50.

81. Salehi, M., \& Ghaderi, A. R. (2012). A Study of Job Satisfaction between External and Internal Auditors: An Iranian Scenario. Research Journal of Applied Sciences, Engineering and Technology, 4 .

82. Sanders ,B. (1998). The Supply of Accounting Graduates And the Demand For Public Accounting Recruits-1996: New York, NY: AICPA.

83. Soobaroyen, T., \& Chengabroyan, C. (2006). Auditors' Perceptions of Time Budget Pressure, Premature Sign Offs and Under-Reporting of Chargeable Time: Evidence from a Developing Country. International Journal of Auditing, 10(3), 201-218 . 
84. Srivastava, S. (2012). Workplace passion as a moderator for workplace deviant behaviour-job satisfaction relationship: A comparative study between public sector and private sector managers. AsiaPacific Journal of Management Research and Innovation, 8(4), 517-523 .

85. Terry, D. J., Gallois, C., \& McCamish, M. (1993). The theory of reasoned action: Its application to AIDS-preventive behavior: Psychology Press.

86. Thompson, J. H., Hodge, T. G., \& Hoskins, M. A. (1997). Audit services: still part of the mix. National Public Accountant, 42, 12-14 .

87. Üç, M., \& Haxhiraj, E. (2015). The Perceptions on IIA's Standards and Internal Audit Quality: Evidence from Albania Banking Industry. Mediterranean Journal of Social Sciences, 6(1), 147 .

88. Utami, I., \& Nahartyo, E. (2013). The Effect of Type a Personality on Auditor Burnout: Evidence from Indonesia. Accounting and Taxation (Forthcoming $\cdot($

89. Vardi, Y., \& Weitz, E. (2002 .(Using the theory of reasoned action to predict organizational misbehavior. Psychological reports, 91(3_suppl), 1027-1040.

90. Watkins, A. L., Hillison, W., \& Morecroft, S. E. (2004). Audit quality: A synthesis of theory and empirical evidence. Journal of Accounting Literature, 23(1), 153-193 .

91. Watts, R. L., \& Zimmerman, J. L. (1986). Positive accounting theory .

92. Willenborg, M. (1999). Empirical analysis of the economic demand for auditing in the initial public offerings market. Journal of Accounting Research .238-225,

93. Yuen, C. Y., Law, K. F. P., Lu, C., \& Guan, J. (2011). Dysfunctional Auditing Behaviour: A Research on Auditors' Behaviour in Macau .

94. Yuniarti, R. (2011). Audit firm size, audit fee and audit quality .

95. Yuniarti, R. (2012). The Effect of Tenure Audit and Dysfunctional Behavior on Audit Quality. Paper presented at the International Conference of Economics, Business and marketing Management.

96. Zureigat, Q. M. (2011). The effect of ownership structure on audit quality: Evidence from Jordan. International Journal of Business and Social Science, 2(10), 38-46. 